\title{
Bo Kong. Modernization through Globalization. Why China Finances Foreign Energy Projects Worldwide. L.: Palgrave Macmillan, 2019. 103 p.
}

\author{
B.B. Ежов \\ Российский университет дружбы народов, Москва, Российская Федерация
}

\section{Bo Kong. (2019). Modernization through Globalization. Why China Finances Foreign Energy Projects Worldwide. L.: Palgrave Macmillan, 103 p.}

\author{
V.V. Ezhov \\ RUDN University, Moscow, Russian Federation
}

\begin{abstract}
Для цитирования: Ежсов В.В. Рецензия: Bo Kong. Modernization through Globalization. Why China Finances Foreign Energy Projects Worldwide. L.: Palgrave Macmillan, 2019. 103 р. // Вестник Российского университета дружбы народов. Серия: Международные отношения. 2019. Т. 19. № 3. С. 518 - 519. DOI: 10.22363/2313-0660-2019-19-3-518-519
\end{abstract}

For citation: Ezhov, V.V. (2019). Book reviw: Bo Kong. (2019). Modernization through Globalization. Why China Finances Foreign Energy Projects Worldwide. L.: Palgrave Macmillan, 103 p. Vestnik RUDN. International Relations, 19 (3), 518 519. DOI: $10.22363 / 2313-0660-2019-19-3-518-519$

Растущее экономическое влияние Китая в мире, его внешняя политика и деятельность в области энергетики привлекают внимание многих российских и зарубежных исследователей. Свой вклад в разработку этих тем внес и исследователь из Университета Оклахомы Бо Конг в своей монографии [Bo Kong 2019].

В рецензируемой работе поставлена задача понять причины, по которым Китай стал крупнейшим инвестором в энергетику, а также исследовать механизмы, благодаря которым это реализуется. Кроме того, автор стремится восполнить пробелы в исследовательской литературе за счет анализа роли финансового сектора, в особенности Китайского банка развития (CDB) и Китайского экспортно-импортного банка (CHEXIM) в гло- бальной экспансии китайских энергетических концернов посредством анализа статистических данных, национальных документов стратегического планирования и отчетов о деятельности упомянутых банков.

Бо Конг констатирует, что в 2009 г. КНР обогнала США по объему международной помощи. Автор строит собственный анализ на достаточно репрезентативном массиве данных о зарубежных проектах в области развития, получивших поддержку КНР в 2000-2017 гг. За 18 лет Китай потратил на указанные проекты в области энергетики более 225 млрд долл. США, причем по географическому признаку они были распределены весьма равномерно: по 28-29 \% на страны Латинской Америки, Европы / СНГ и Азии и $15 \%$

(C) Ежов В.В., 2019

(c) This work is licensed under a Creative Commons Attribution 4.0 International License https://creativecommons.org/licenses/by/4.0/ 
на Африку. Что касается сферы приложения инвестиций, то более $70 \%$ всех средств в рассматриваемый период были вложены в углеводороды.

Автор полагает, что такая глобальная активность проистекает из стремления Китая решить задачу модернизации страны, которую можно назвать разделяемой всеми национальной идеей на протяжении почти ста лет [Bo Kong 2019: 26]. Сейчас тема модернизации приобрела форму двух «целей столетия», которых необходимо достичь к 2021 и 2049 гг.

В качестве четырех зон риска, или «мягких подбрюший», китайской модернизации идентифицированы зависимость от зарубежных ресурсов, доступ к иностранным рынкам сбыта (в целях загрузки избыточных производственных мощностей Китая), передовым технологиям (для обеспечения лидерства в области инноваций), а также растущие валютные риски для Китая как крупнейшего держателя резервов в иностранной валюте (особенно в долларах США) [Bo Kong 2019: 31].

Исходя из этого, посредством финансирования зарубежных проектов КНР будет стремиться получить доступ к ресурсам, рынкам сбыта и технологиям, а также повышать международный статус юаня.

Особое внимание Бо Конг уделяет механизмам государственного контроля за двумя ключевыми банками, выделяя стратегический (нормативно-правовое регулирование, назначение руководителей на ключевые позиции) и оперативный уровни (представительство Министерства финансов, Банка Китая, Госсовета по развитию и реформам и др. в советах директоров). Отдельно отмечен вклад государства в мобилизацию финансовых ресурсов для банков посредством присвоения им высоких кредитных рейтингов (на уровне надежности государственных облигаций) [Во Kong 2019: 72] и прямых денежных вливаний. Такая система позволяет трансформировать де-факто краткосрочные инструменты заимствования в кредиты для зарубежных партнеров на реализацию средне- и долгосрочных проектов.

Несмотря на объективный подход к проведению исследования, ряд факторов, на наш взгляд, снижают практическую значимость монографии. Так, использованный массив данных по проектам не включает в себя финансирование, идущее в иностранные государства по линии китайских энергетических концернов, в том числе в качестве прямых иностранных инвестиций, что может свидетельствовать о неполной достоверности результатов применительно к географическому и секторальному распределению китайских вложений в зарубежные энергетические проекты и как следствие - подрывать достоверность сделанных теоретических и практических выводов.

В целом можно признать, что монография Бо Конга - серьезное и достаточно комплексное исследование, дополняющее имеющуюся литературу по проблематике внешней политики Китая и позиционированию страны на международной арене. Хотя некоторые подходы к исследованию и сделанные с их помощью выводы не отражают всю полноту картины, монография, несомненно, будет полезна китаистам и исследователям проблем развития, а также широкому кругу аналитиков.

Поступила в редакцию / Received: 09.09.2019

Принята к публикации / Accepted: 25.09.2019

\section{Библиографический список / References}

Bo Kong. (2019). Modernization through Globalization. Why China Finances Foreign Energy Projects Worldwide. L.: Palgrave Macmillan.

Сведения об авторе: Ежов Вадим Владимирович - аспирант кафедры теории и истории международных отношений Российского университета дружбы народов (e-mail: wading@rambler.ru).

\footnotetext{
About the author: Ezhov Vadim Vladimirovich — postgraduate student, the Department of Theory and History of International Relations, RUDN University (e-mail: wading@rambler.ru).
} 